\title{
TOXICOLGICAL AND BIOCHEMICAL EFFECTS OF SOME RECOMMENDED AND ALTERNATIVE COMPOUNDS ON COTTON LEAFWORM Spodoptera littoralis (BOISD) (LEPIDOPTERA:NOCTUIDE) IN COTTON FIELDS. \\ Said,A.A.A. ${ }^{\text {; }}$ M.M. Kady ${ }^{1}$;H.M.H.Al-Shannaf ${ }^{2}$;Salwa E. Negm ${ }^{1}$ and M.A.S. Salama ${ }^{2}$ \\ 1 pesticide Department, Faculty of Agric, Mansoura, Univ. 2 Plant Protection Institute
}

\begin{abstract}
Field and laboratory experiments were carried out to evaluate the two insect growth (IGRs), lufenuron and teflubenzuron, antifeedant compoundindoxacab, miniral oil(Kz oil), compound Protecto, Bacillus thuringinsis(Bt)and Dursban, chlorpyrifos against the larvae of cotton leafworm, Spodoptera littoralis(Boisd.).Field experiment conducted during 2013 and 2014 seasons at KafrSakrregion, SharkyiaGovernorate, Egypt. Results revealed that,chlorpyrifos recordedhighest initial reduction (89.38 and $88.39 \%$ ), residual mean (88.52 and $87.72 \%$ ) and annual mean (87.74 and $87.37 \%$ ) onSpodoptera littoralis during the two successive seasons, respectively.

In regarding to the biochemical activites of treated larvae in laboratory the all tested compoundsdisruptedthe testedactivities. The highest effect on the total soluble protein as specific activity( SA) of $40.57 \mathrm{mg} / \mathrm{g} . \mathrm{bwt}$ recorded for $4^{\text {th }}$ instar larvae treated with $\mathrm{LC}_{50}$ concentration of chlorpyrifose and sampled after 3 days of treatment, while the highest reduction in relative activity (RA\%) of $-54.15 \%$ recorded for larvae treated with $\mathrm{LC}_{50}$ concentration of Betavant and sampled after 3 days also. The tested compounds at selected concentrations of $\mathrm{LC}_{25}$ and $\mathrm{LC}_{50}$ also disrupted GOT and GPT activities of treated larvae where the highest GOT as SA $\left(2574.33 \pm 30.4 \mathrm{u} * 10^{3} \mathrm{~g}\right.$.sbwt) recorded for larvae treated with $\mathrm{LC}_{25}$ concentration and sampled after 3 days of treatment, while the highest relative activity RA\% $-43.36 \%$ was exhibited in case of after 7 days of treat.the larvae treated with chlorpyrifose and sampled. The highest effect on GPT as SA $\left(711.33 \pm 5.2 \mathrm{u} * 10^{3} \mathrm{~g}\right.$. bwt) was recorded for larvae treated with Komatch at concentration of $\mathrm{LC}_{25}$ and sampled at 3rd days of treatment, while the highest relative activity\% -64.05 recorded for larvae treated with $\mathrm{LC}_{50}$ concentration of Betavant and sampled at $3^{\text {rd }}$ day of treatment also. Inregarding to the effect of tested compounds on carbohydrate hydrolyzing enzymes;invertase, trehalase and amylase determined as $\mu \mathrm{g}$ glucose/min g.bwt/days. The highest values were 405.679 $\pm 9.03,222.33 \pm 7.26$ and $123 \pm 3.31$ recorded for larvae treated with $\mathrm{LC}_{25} \mathrm{of} \mathrm{Kz}_{\mathrm{oil}}$, $\mathrm{LC}_{50}$ of $\mathrm{Kz}$ oil and $\mathrm{LC}_{25}$ of Betavant sampled at $3^{\text {rd }}$ day of treatment for invertase, trehalase and amylase enzymes, respectively.On the other hand, the highest relative activity RA\% of $-0.53,-0.44$ and -0.61 were recorded for larvae treated with $\mathrm{LC}_{50}$ of Nomult (at 3days of treatment), $\mathrm{LC}_{25}$ of Nomult (at $3^{\text {rd }}$ day of treatment) and $\mathrm{LC}_{50}$ of $\mathrm{Kz}$ oil (at 7 days of treatment) that for invertase, trehalase and amylase, respectively.
\end{abstract}

Keywords: Spodopteralittoralis(Boisd.),Toxicity, Biochemical,IGRs, indoxacarb,mineral oil, Bacillus thuringnsis( Bt).

\section{INTRODUCTION}

In Egypt,Cotton leafworm, Spodopteralittorlis (Boisd.) (Lepidoptera: Nectuidae) is a serious lepidopteran pest of cotton through its different growth stages, where the larvae are heavily attacking cotton causing severe damage and consequently reduction in the obtained yield,(Pluschkellet al., 1998and Korratetal.,2012) .Tocontrol cotton leafworm, many compounds use from different pesticides groups, biopesticides, oils and plant extracts. The antifeedantcompound, indoxcarb (Betavant 5\% EC) was effected the newly ecdysed $2^{\text {nd }}$ and $4^{\text {th }}$ instars larvae of S. littoralis and the $\mathrm{LC}_{50}, \mathrm{LC}_{90}$ values, were 0.63 and $3.1 \mathrm{ppm}$ for the $2^{\text {nd }}$ instar and $2.0 \& 18.75 \mathrm{ppm}$ for the $4^{\text {th }}$ instar larvae. That mean the $2^{\text {nd }}$ instar larvae was more susceptible to indoxacarb more than the $4^{\text {th }}$ one( Al-Shannafet al. 2012).Al-Shannaf and Ammar (2011) stated that, the Radical(Avermectin)compound gave highest initial reductionpercentage against $S$.littoralis and Helicoverpaarmigra followed by Dursban (chlorpyrifose), mixture of Consult (IGR) and Dursban only, where the lowest reduction percentage was recorded for Dipel $\mathrm{DF}(\mathrm{Bt})$. As results ofMohamed et al.( 2006), the mineral oil Kapl-2 at rate of 1.5 and $0.75 \%$ showed low effect on S.littoralisin comparison by the insecticide,Actellic (pirimiphose methyl).In the same trend, the mineral oil, Kemesol95\% used as topical application reduced hemolymph fat body and total soluble protein of $S$. littoralis, (Khatter and Abuldahb,2010). The IGR compound, teflubenzoronaffected GOT enzymes activities and total soluble protein for $S$. littoralis larvae significantly, while its effect on GPT, was a significant reduction, (EL-Kordyetal., 1995) and Desuky, et al., 2005).The insecticide Betavant (Indoxacarb) caused slightly increasing in total protein content of $S$. littoralis $2^{\text {nd }}$ instar larvae by $8.79 \%$, while it decreased total soluble protein by $24.9 \%$ in $4^{\text {th }}$ instar and disrupted carbohydrate enzymes,as results of Gmail et al.(2011). Also, the bacterial insectbiocideB.thuringensis and $\mathrm{Kz}$ oil reduced the total protein content of treated S. littoralis(Zidanet al., 1996).

This work aimed to study the toxic (as field trials) and physiological (as laboratory trials) effects of some recommended and alternative compounds, i.e, Komatch,Nomult, Betavant, $\mathrm{Kz}$ oil, Protecto and Dursban against cotton leafworm, S. littoralis.

\section{MATERIALS AND METHODS}

\section{Tested Compound:}

1. Insect growth regulators (IGRs):

- Komatch, Lufenuron5\% EC used at rate of 160 $\mathrm{cm} /$ feddan 
- Nomult,Teflubenzuron 5\% EC used at rate of 160 $\mathrm{cm} /$ feddan.

2. Antifeedant compound: Betavant, indoxacarb $14.3 \%$ $\mathrm{SC}$ used at rate of $110 \mathrm{~cm} /$ feddan.

3. Meniraloil, $\mathrm{Kz}$ oil $95 \% \mathrm{EC}$ used at rate of 1500 $\mathrm{ml} / 100$ litter water.

4. BactarialCompound: Protecto, Bacillus thurinigiensis $9.4 \%$ WPat rateof $300 \mathrm{gm} /$ feddan

5. Organphosphorus insecticide:Dursban, chlorpyrifos $48 \%$ E.C. used at rate $1000 \mathrm{ml} /$ Feddan.

Field trials:

Field experiments were carried out at KafrSakrregion, SharkyiaGovernorate, Egypt during two consecutive cotton growing seasons of 2013and2014.The experimentarea of two faddan was divided into 6 treatments and one as control (and each replicated three times). The experiment area was cultivated with the Egyptian cotton variety, Giza 86.Cotton plants treated once with each compound at $24^{\text {th }}$ and $21^{\text {th }}$ June during the considered seasons, respectively. Thesamplesof 100 plants/ replicate was inspected in field and $1^{\text {st }}, 2^{\text {nd }}, 3^{\text {rd }}$ and $4^{\text {th }}$ instars larvae were counted and recorded, Just before treatment and after 1,7 and 10days for Dursban treatment,while it examined at 3,7and10 dyes for each of Komatch, Nomult,Betavant, Kzoil and Protecto. The reduction percentages of cotton leafworm larvae were calculated use equationof Henderson and Tilton (1955).

\section{1-Insect Rearing:}

Cotton leafworm, Spodoptera littoralislarvae were obtained from a culture reared in cotton leafworm laboratory at Plant Protection Research Institute Sharkia branchwithout exposure history to insecticide. Larvae were reared on fresh castor bean leaves, Ricinuscomnuis L.All laboratory trials were kept under laboratory condition of $27 \pm 2 \mathrm{C}^{\circ}$ and $\mathrm{RH} \% 70 \pm 5 \%$.

\section{Laboratory treatment:}

10 individuals The cotton leafworm $4^{\text {th }}$ instar larvae were put in glass Jar, replicated 4 time for each treatment and labeled as treatments and control.

Table (1): $\mathrm{LC}_{50}$ and $\mathrm{LC}_{25}$ values of the tested compounds

\begin{tabular}{lccccccc}
\hline Compound & Komatch* & Nomult* & Betavant* $^{*}$ & Kzoil* $^{*}$ & Protecto** & Dursban* & Control* \\
\hline $\mathrm{LC}_{25}$ & 2.52 & 1.17 & 0.16 & 5521.01 & 82.24 & 6.66 & 0.00 \\
$\mathrm{LC}_{50}$ & 12.08 & 15.89 & 1.41 & 27734.36 & 303.42 & 31.24 & 0.00 \\
\hline
\end{tabular}

* Concentration in ppm ** Concentration as international unit

Table (1) cleared that,the $\mathrm{LC}_{25}$ and $\mathrm{LC}_{50}$ concentrations were prepared aswater solution and the castor bean leaves were cleaned and dipped in each separately. The dipped castor bean leaveswere left for $30 \mathrm{~min}$. to complete dryness on table under laboratory conditions. After that, the treated leaves of each concentration ofeach compound deliveredto the $4^{\text {th }}$ instar larvae in glass jars as well as the leaves dipped in water only as control.The larvae were fed on treated castor leaves for three days for all treatment except of Dursban which fed for 24 h.only, then the all fed on untreated leaves tell the end of experiment.

\section{Samples preparation:}

The $4^{\text {th }}$ instar larvae samples were collected at 3; 7 days post treatment with $\mathrm{LC}_{25}$ and $\mathrm{LC}_{50}$ concentrations of each tested compound as well as untreated one. Samples were homogenized in distilled water using a Teflonhomogenizer, the homogenates werecentrifugedat $5000 \mathrm{rpm}$ for $10 \mathrm{~min}$. at $5^{\circ} \mathrm{C}$ the supernatants were immediately assayed to determine the total soluble protein, the activities of aspartate amino transferase (Got) and a alanine amino transferase (GPT)and the carbohydrate hydrolyzing enzymes(Trehalase, Invertase and Amylase).

\section{Determination of biochemical activities: a- Carbohydrate hydrolyzing enzymes:}

The method used to determine the activities of carbohydrate hydrolyzing enzymes (Trehalase, Invertase and Amylase) digesting sucrose Trehalase and starch, respectively, were illustrated by Ishaaya and Swiriski (1976). The free aldehydes group of glucose after starch, Trehalase and sucrose digestion was determined use 3, 5 dinitro salicylic acid regent.

\section{b- Determination of total soluble protein:}

Colorimetric determination of (TSP) total homogenized $S$. littoralis larvae was carried out as described by Bradford,M.M.(1976). Protein reagent was prepared by dissolving $100 \mathrm{mg}$ of Coomassie Brilliant blue G-250 in $50 \mathrm{ml} 85 \%(\mathrm{~W} / \mathrm{V})$ Phosphoric acid were added .The resulting solution was diluted to a final volume of 1liter.

\section{c- Transaminase enzymes determination:}

Aspartate amino transferase (GOT) and alanine amino transferase (GPT) enzyme activities were determined calorimetrically according to method of (Reitmin and Frankal 1957).

Statistical analysis:

One way ANOVA was used to determine the significance of differences between, means of values obtained in the field experiment.

\section{RESULTS AND DISSCUION}

\section{1-Field evaluation of tested compounds on cotton leafworm:}

The obtained results in Table (2) showed thatthe initial effect as reduction percentages of the cotton leafworm larvae in fields sprayed with recommended concentration of the tested compound at 2013 season were $81.71,83.61,41.18,7.53$ and $11.09 \%$ after 3 days of spray with lufenuron,teflubezuron,indoxacarb,Kzoil and BT respectively, while it was $89.53 \%$ after one day for chlorpyrifose. Asresidual effect, the reduction percentages were 87.66,85.07,45.94,8.54 and $13.52 \%$ after 7 days and were $88.93,86.78,53.00,14.21$ and $18.29 \%$ after 10 days forlufenuron ,teflubezuron, indoxacarb, $\mathrm{Kz}$ oil and B.thuringinsis ,receptively, 
recorded 87.66 and $86.38 \%$ forchlorpyrifosafter 7 and 10 days of application,respectively. The insecticide chlorpyrifos recorded the highest reduction percentage of $87.74 \%$ while $\mathrm{Kz}$ oil recorded the lowest one $8.87 \%$.

Table (2): Reduction percentage of some alternative compounds against cotton leafworm, Spodoptera littoralis compared withDursban in cotton fields during 2013 season.

\begin{tabular}{|c|c|c|c|c|c|c|c|c|}
\hline \multirow{2}{*}{\multicolumn{2}{|c|}{ Treatments }} & \multirow{2}{*}{ Pre-count } & \multicolumn{2}{|c|}{ Initial } & \multicolumn{2}{|c|}{ Residual } & \multirow{2}{*}{ Mean } & \multirow{2}{*}{ Annual mean } \\
\hline & & & 1day & 3days & 7days & 10days & & \\
\hline \multirow[t]{2}{*}{ Komatch } & No. & 121.25 & - & 17.93 & 17.08 & 22.56 & 19.82 & 19.19 \\
\hline & $\%$ & - & - & 88.93 & 86.17 & 81.71 & 8.94 & 85.60 \\
\hline \multirow[t]{2}{*}{ Nomolt } & No. & 147.61 & - & 20.20 & 22.78 & 25.05 & 23.92 & 22.68 \\
\hline & $\%$ & - & - & 86.78 & 85.07 & 83.61 & 83.84 & 85.15 \\
\hline \multirow[t]{2}{*}{ Betavant No. } & No. & 143.25 & - & 68.19 & 78.70 & 85.34 & 82.02 & 77.61 \\
\hline & $\%$ & - & - & 53.00 & 45.94 & 41.18 & 43.66 & 46.71 \\
\hline \multirow{2}{*}{ KZ oil } & No. & 141.28 & - & 128.83 & 132.22 & 133.22 & 132.72 & 131.42 \\
\hline & $\%$ & - & - & 14.21 & 8.54 & 7.53 & 8.04 & 8.87 \\
\hline \multirow{2}{*}{ Protecto } & No. & 136.97 & - & 113.75 & 120.53 & 123.78 & 122.16 & 119.35 \\
\hline & $\%$ & - & - & 18.29 & 13.52 & 11.09 & 12.32 & 14.30 \\
\hline \multirow{2}{*}{ Dursban } & No. & 165.81 & 17.78 & - & 20.91 & 22.83 & 19.35 & 20.51 \\
\hline & $\%$ & - & 89.38 & - & 87.66 & 86.53 & 88.52 & 87.74 \\
\hline \multirow{2}{*}{$\begin{array}{l}\text { Control } \\
\qquad \begin{array}{c}\text { F. test } \\
\text { LSD }_{0.05}\end{array}\end{array}$} & No. & 153.97 & 151.77 & 156.70 & 159.61 & 162.89 & 161.25 & $\begin{array}{c}159.73 \\
* *\end{array}$ \\
\hline & & & & & & & & 6.17 \\
\hline
\end{tabular}

During 2014 season, data in Table (3)showed that the initial effect as reduction percentages of cotton leafworm larvae after 3 days of field spraywere83.48,82.11,43.44,7.42and11.17\%forlufenuro $\mathrm{n}$, teflubezuron , indoxacarb ,Kz oil and B.thuringinsis, respectively, while it was $88.39 \%$ for chlorpyrifose after one day of spray.The residual effect recorded after 7 and 10 days of application cleared that the chlorpyrifoserecorded highest reduction percentage of
$87.06 \quad \& \quad 88.36 \%$ followed descendingly by84.91,83.76,46.97,8.16 \& $13.49 \%$ at 7 days and $83.48,82.11,43.44,11 . \& .42 \%$ at10 days for lufenuron, teflubezuron, indoxacarb, B.thuringinsisand $\mathrm{Kz}$ oil, respectively; in the field population of the cotton leafworm larvae in sprayed fields. These results found in agreement with those of Mohamed et al. (2006); ALShannaf and Ammar (2011) and Barrania(2013).

Table (3): Reduction percentage of some alternative compounds against cotton leafworm, Spodoptera littoralis compared with Dursban in cotton fields during 2014 season.

\begin{tabular}{|c|c|c|c|c|c|c|c|c|}
\hline \multirow{2}{*}{\multicolumn{2}{|c|}{ Treatments }} & \multirow{2}{*}{ Pre-count } & \multicolumn{2}{|c|}{ Initial } & \multicolumn{2}{|c|}{ Residual } & \multirow{2}{*}{ Mean } & \multirow{2}{*}{ Annual mean } \\
\hline & & & 1 day & 3 days & 7 days & 10 days & & \\
\hline 矛 & No. & 14766 & - & 19.09 & 22.67 & 24.73 & 23.70 & 22.16 \\
\hline 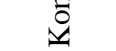 & Reduction \% & & - & 86.75 & 84.91 & 83.48 & 84.49 & 85.04 \\
\hline 훙 & No. & 125.81 & - & 29.49 & 30.79 & 33.88 & 32.34 & 31.39 \\
\hline$\stackrel{\circ}{Z}$ & Reduction $\%$ & - & - & 84.45 & 83.76 & 82.11 & 82.94 & 83.44 \\
\hline 芯 & No. & - & - & 83.86 & 93.88 & 97.80 & 95.84 & 91.85 \\
\hline D & Reduction \% & - & - & 52.62 & 46.97 & 43.44 & 45.21 & 47.67 \\
\hline$\overline{0}$ & No. & 174.11 & - & 162.17 & 171.46 & 172.83 & 172.15 & 168.82 \\
\hline 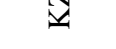 & Reduction \% & - & - & 13.13 & 8.16 & 7.42 & 7.79 & 9.57 \\
\hline$\stackrel{0}{0}$ & No. & 183.65 & - & 159.51 & 165.87 & 169.79 & 167.83 & 165.06 \\
\hline$=$ & Reduction \% & - & - & 16.65 & 13.49 & 11.17 & 12.34 & 13.77 \\
\hline Еี & No. & 188.17 & 19.73 & - & 23.32 & 24.64 & 21.53 & 22.56 \\
\hline$\tilde{\Delta}$ & Reduction \% & 176.59 & 88.39 & - & 87.06 & 86.34 & 87.72 & 87.37 \\
\hline $\begin{array}{c}\text { Control } \\
\text { F. test }\end{array}$ & No. & 186.77 & 187.97 & 189.42 & 191.80 & 193.81 & 192.91 & $\begin{array}{c}191.68 \\
* *\end{array}$ \\
\hline $\mathrm{LSD}_{0.05}$ & & & & & & & & 6.16 \\
\hline
\end{tabular}

The statistical analysis results clearedthat there are significant differences between Dursban, Komatch and Nomult ashigh efficacycompounds, Betavant as moderateefficacycompound and the lowest efficacy group, $\mathrm{Kz}$ oil and Btcompound, that as initial effect $(\mathrm{LSD}=6.16)$ and as residual effect after 7 days 
(LSD=7.37).The same trend was noticed for general mean and residual mean with $\mathrm{LSD}=6.46$ and 6.16 ,respectively.

2-Laboratory trials: Biochemical responses of cotton leafworm, $S$. littoralis larvae to the tested compound:

The physiological changes of $\boldsymbol{S}$. littoralis $4^{\text {th }}$ instar larvae assessed at 3 and 7 days after treatment with $\mathrm{LC}_{25}$ and $\mathrm{LC}_{50}$ concentrations of the tested compoundswere determined as, effects on the activities of carbohydrate hydrolyzing enzymes (Invertase, Trehalase and amylase) ,the total soluble protein concentration and transaminase( GOTandGPT) were determined.

a- carbohydrate hydrolyzing enzymes activities:

Data presented in table (4) indicated that, the all tested compounds were effected the activities of amylase, Invertase and Trehalase enzymes in the treated $4^{\text {th }}$ instar larvae of S. littoralis.

\section{- Invertase}

In case of the effect of $\mathrm{LC}_{25}$ concentration of tested compound on invertase activity in treated and untreated $4^{\text {th }}$ instar larvae sampled after 3 days of treatment as SA and RA\% in treated larvae in relation to untreated ones. The highest effect on Invertase was recorded in larvae treated with $\mathrm{Kz}$ oil $(405.67 \pm 9.03 \mu \mathrm{g}$ glucose / min / g. bwt days) recorded increase in RA\% of $0.25 \%$ in compared with untreated larvae while the lowest SA was recorded in larvae treated with Nomult $(204 \pm 6.91 \mu \mathrm{g}$ glucose / $\mathrm{min} / \mathrm{g}$. bwt days) recorded reduction of $-0.37 \%$ in compared with $(325 \pm 5.209 \mu \mathrm{g}$ glucose / $\mathrm{min} / \mathrm{g}$. bwt days) for untreated larvae.

In the same trend, the result of $\mathrm{LC}_{50}$ treatment effect after 3 days cleared that the highest SA was recorded in larvae treated with $\mathrm{Kz}$ oil $(365.67 \pm 6.39 \mu \mathrm{g}$ glucose / $\mathrm{min} /$ g.bwt days) recorded relative increase of $0.13 \%$ in compared with untreated larvae while the lowest was recorded with Nomult $(154.67 \pm 2.23 \mu \mathrm{g}$ glucose / $\min /$ g.bwt) recorded reduction of $-0.53 \%$ in compared with $325 \pm 12.04 \mu \mathrm{g}$ glucose / min / g. bwt days) for untreated larvae.

Table (4): Changes in invertase,trehalase and amylase enzymes activities in $S$. littoralistreated with multiple compounds and chemical pesticide

\begin{tabular}{|c|c|c|c|c|c|c|c|c|}
\hline \multirow[t]{2}{*}{ Treatments } & \multirow{2}{*}{\multicolumn{2}{|c|}{ Con. ppm }} & \multicolumn{2}{|c|}{$\begin{array}{c}\text { Invertase (Ug } \\
\text { glucose/min/g.b.wt/days }\end{array}$} & \multicolumn{2}{|c|}{$\begin{array}{c}\text { Trehalase Ug } \\
\text { glucose/min/g.b.wt }\end{array}$} & \multicolumn{2}{|c|}{$\begin{array}{c}\text { Amylase Ug } \\
\text { glucose/min/g.b.wt }\end{array}$} \\
\hline & & & 3 days & 7 days & 3 days & 7 days & 3 days & 7 days \\
\hline \multirow{5}{*}{ Komatch } & \multirow{2}{*}{25} & SA & $260.00 \pm 3.78$ & $270.67 \pm 4.34$ & $121.33 \pm 4.54$ & $212.33 \pm 6.24$ & $88.33 \pm 2.23$ & $91.67 \pm 4.18$ \\
\hline & & RA \% & -0.20 & 0.09 & -0.28 & -0.07 & 0.11 & -0.06 \\
\hline & \multirow{2}{*}{50} & SA & $212.00 \pm 1.42$ & $247 \pm 4.05$ & $129.67 \pm 4.75$ & $201.33 \pm 6.37$ & $46.33 \pm 1.52$ & $103.67 \pm 0.88$ \\
\hline & & RA \% & -0.35 & -0.01 & -0.23 & -0.12 & -0.42 & 0.07 \\
\hline & \multirow{2}{*}{25} & SA & $204.00 \pm 6.91$ & $236 . .33 \pm 3.18$ & $95.67 \pm 3.14$ & $243.33 \pm 3.39$ & $82.00 \pm 2.63$ & $115.33 \pm 3.72$ \\
\hline \multirow{3}{*}{ Nomolt } & & RA \% & -0.37 & -0.05 & -0.44 & 0.07 & 0.03 & 0.19 \\
\hline & \multirow{2}{*}{50} & $\mathrm{SA}$ & $154.67 \pm 2.23$ & $244.00 \pm 3.61$ & $72.67 \pm 1.79$ & $251.67 \pm 5.79$ & $57.33 \pm 3.20$ & $104.67 \pm 3.85$ \\
\hline & & RA \% & -0.53 & -0.02 & -8.57 & 0.10 & -0.28 & 0.08 \\
\hline \multirow{5}{*}{ Betavant } & \multirow{2}{*}{25} & SA & $312.67 \pm 4.96$ & $256.33 \pm 4.85$ & $181 \pm 3.10$ & $204.33 \pm 7.18$ & $123.00 \pm 3.31$ & $100.67 \pm 3.39$ \\
\hline & & RA \% & -0.04 & 1.33 & 0.07 & -0.11 & 0.54 & 0.04 \\
\hline & \multirow{2}{*}{50} & SA & $310.67 \pm .4 .39$ & $250.00 \pm 5.52$ & $155.33 \pm 1.66$ & $218.00 \pm 4.73$ & $102.67 \pm 2.33$ & $92.67 \pm 1.77$ \\
\hline & & RA \% & -0.05 & 0.01 & -0.001 & -0.05 & 0.28 & -0.05 \\
\hline & \multirow{2}{*}{25} & SA & $405.67 \pm 9.03$ & $149.33 \pm 15.19$ & $208.00 \pm 6.08$ & $145.33 \pm 3.49$ & $89.00 \pm 1.25$ & $77.00 \pm 4.05$ \\
\hline \multirow{3}{*}{ KZoil } & & RA \% & 0.25 & -0.40 & 0.23 & -0.37 & 0.11 & -0.21 \\
\hline & \multirow{4}{*}{25} & SA & $365.67 \pm 6.39$ & $147.33 \pm 7.43$ & $222.33 \pm 7.26$ & $112.33 \pm 6.24$ & $105.33 \pm 3.58$ & $38.00 \pm 2.52$ \\
\hline & & RA \% & 0.13 & -0.41 & 0.32 & -0.51 & 0.32 & -0.61 \\
\hline \multirow{4}{*}{ Protecto } & & SA & $279.67 \pm 7.65$ & $236.00 \pm 6.04$ & $166.33 \pm 2.89$ & $210.00 \pm 1.53$ & $58.33 \pm 2.69$ & $105.67 \pm 3.18$ \\
\hline & & RA \% & -0.14 & -0.06 & -0.02 & -0.08 & -0.27 & 0.09 \\
\hline & \multirow{2}{*}{50} & SA & $242.33 \pm 10.17$ & $253.00 \pm 7.52$ & $104.00 \pm 3 . .46$ & $247.33 \pm 3.85$ & $36.00 \pm 2.50$ & $91.33 \pm 1.86$ \\
\hline & & RA \% & -0.26 & 0.01 & -0.39 & -0.08 & -0.55 & -0.06 \\
\hline \multirow{4}{*}{ Dursban } & \multirow[t]{2}{*}{25} & SA & $246.33 \pm 5.63$ & $179.67 \pm 1.86$ & $149.00 \pm 9.44$ & $279.67 \pm 7.23$ & $92.00 \pm 1.441$ & $64.33 \pm 2.73$ \\
\hline & & RA \% & -0.24 & -0.20 & -0.12 & 0.22 & 015 & -0.34 \\
\hline & \multirow{2}{*}{50} & SA & $215.00 \pm 6.39$ & $189.67 \pm 6.07$ & $154.67 \pm 6.55$ & $258.67 \pm 4.10$ & $93.00 \pm 3.88$ & $43.00 \pm 3.52$ \\
\hline & & RA \% & -0.34 & -0.24 & -0.09 & 0.13 & 0.16 & -0.56 \\
\hline
\end{tabular}

$\mathbf{S A}=$ Specific activity

\section{RA \% $=$ Relative concentration \\ Treatment - control \\ Control}

The effect of $\mathrm{LC}_{25}$ concentration of tested compound on Invertase activity in treated and untreated $4^{\text {th }}$ instar larvae sampled at 7 days after treatment as SA and $\mathrm{RA} \%$ in treated larvae in relation to untreated ones. The highest AS was recorded in larvae treated with
Komatch $(270.67 \pm 4.34 \mu \mathrm{g}$ glucose / min / g.bwt days $)$ recorded increase in RA\% by $0.09 \%$ in compared with untreated larvae. While the lowest SA was recorded in larvae treated with $\mathrm{Kz}$ oil $(149.33 \pm 15.19 \mu \mathrm{g}$ glucose/ $\mathrm{min} /$ g.bwt days) recorded reduction of $-0.40 \%$ in 
compared with $249.67 \pm 11.85 \mu \mathrm{g}$ glucose / min / g.bwt days for untreated larvae.

In case of $\mathrm{LC}_{50}$ treatment after 7days, The highest effect was recorded on larvae treated by Betavant $(250 \pm 5.52 \mu \mathrm{g}$ glucose min g.bwt days) recorded increase in RA\% by $0.01 \%$ in compared with untreated ones, while the lowest effect was recorded with $\mathrm{Kz}$ 0il (147.33 $\pm 7.43 \mu \mathrm{g}$ glucose / $\mathrm{min} / \mathrm{g} . \mathrm{bwt}$ days) recorded reduction of $-0.41 \%$ in compared with $249.67 \pm 11.85 \mu \mathrm{g}$ glucose / min / g.bwt days for untreated larvae.

The results above found agree those of Ahmed, et al. (1990); Kandil, (2005); EL-Kordy, et al. (1995); and Gamil,et al.(2011).recorded that the $\mathrm{Kz}$ oil effected invertase activity in $S$. littoralis.

\section{- Trehalase}

Data in table (4) showed the effect of $\mathrm{LC}_{25}$ concentration of tested compound on trehalase activity in treated and untreated $4^{\text {th }}$ instar larvae after 3 days as SA and RA\% in treated larvae in relation to untreated ones. The highest effect on trehalase was recorded in larvae treated with $\mathrm{Kz}$ oil $(208 \pm 6.02 \mu \mathrm{g}$ glucose / min / g.bwt days) recorded increase in RA\% by $0.23 \%$ in compared with untreated larvae, while, the lowest SA was recorded in larvae treated with Nomult $(95.67 \pm 3.14$ $\mu \mathrm{g}$ glucose / min / g.bwt days) recorded increase in RA\% by $0.44 \%$ in compared with $169 \pm 5.72 \mu \mathrm{g}$ glucose / min / g. bwt days for untreated larvae.

In the same trend, the results ofLC $\mathrm{C}_{50}$ treatment after 3 days cleared that the highest effect on Trehalase was recorded in larvae treated with $\mathrm{Kz}$ oil $(169 \pm 5.72 \mu \mathrm{g}$ glucose / $\mathrm{min} / \mathrm{g}$ bwt days) recorded increase in RA\% by $0.32 \%$ compared with untreated larvae, while the lowest effect was recorded in larvae treated use Nomult $(72.67 \pm 1.79 \mu \mathrm{g}$ glucose / $\mathrm{min} / \mathrm{g}$. bwt days )recorded reduction of $-8.57 \%$ compared with for untreated larvae

The effect of $\mathrm{LC}_{25}$ concentration of tested compound on Trehalase activity in treated and untreated $4^{\text {th }}$ instar larvae sampled after 7 days of treatment as SA and RA\% in treated larvae compared with untreated ones. The highest SA was recorded in larvae treated with Dursban $(279.07 \pm 7.23 \mu \mathrm{g}$ glucose/ $\mathrm{min} / \mathrm{g}$. bwt days) recorded increase in RA\% by $0.22 \%$ in compared with untreated larvae, while the lowest effect was recorded in larvae treated with $\mathrm{Kz}$ oil $(145.33 \pm 3.49 \mu \mathrm{g}$ glucose / min / g. bwt days) recorded reduction of $0.37 \%$ in compared with $(222.57 \pm 12.72 \mu \mathrm{g}$ glucose / $\min / \mathrm{g}$ bwt days ) for untreated larvae .

The results of $\mathrm{LC}_{50}$ treatment after 7 days revealed that the highest $\mathrm{SA}$ was recorded in larvae treated with Dursban $(258.57 \pm 5.09 \mu \mathrm{g}$ glucose/ $\mathrm{min} / \mathrm{g}$. bwt days) recorded increase in RA\% by $0.13 \%$ compared with untreated larvae, while the lowest SA was recorded in larvae treated with $\mathrm{Kz}$ oil $(112.33 \pm 6.24$ $\mu \mathrm{g}$ glucose / $\mathrm{min} / \mathrm{g}$. bwt days) recorded reduction of $0.51 \%$ in compared with $(222.57-+12.72 \mu \mathrm{g}$ glucose/ $\mathrm{min} / \mathrm{g}$. bwt days) for untreated larvae

The results of these trial found in agreement with those of Ayyangar and Rao (1990); Kandill (2000); Desuky, et al. (2005);Omar et al. (2005) and (Sabry and
Khedr, 2014) .The IGRs and chlorpyrifoseeffected Trehalase activity in S. littoralis.

\section{- Amylase}

Data in table (4) showed the effect of $\mathrm{LC}_{25}$ concentration of tested compound on amylase activity in treated and untreated $4^{\text {th }}$ instar larvae after 3 days of treatment as SA and RA\% in treated larvae in relation to untreated ones. The highest effect on amylase was recorded in larvae treated with Betavant $(123 \pm 3.31 \mu \mathrm{g}$ glucose / $\mathrm{min} / \mathrm{g}$. bwt days) recorded increase in RA\% by $0.54 \%$ in compared with untreated larvae, while the lowest SA was recorded in larvae treated with Protecto $(58.33 \pm 2.69 \mu \mathrm{g}$ glucose / $\mathrm{min} / \mathrm{g}$. bwt days) recorded reduction of $-27 \%$ in compared with $(80.0 \pm 4.33 \mu \mathrm{g}$ glucose/ $\mathrm{min} / \mathrm{g}$. bwt days) for untreated larvae.

The results of $\mathrm{LC}_{50}$ treatment after 3days showed that The highest SA was recorded in larvae treated with $\mathrm{Kz}$ oil $(105.33 \pm 3.58 \mu \mathrm{g}$ glucose / $\mathrm{min} / \mathrm{g}$. bwt days $)$ recorded increase in RA\% by $0.32 \%$ in compared with untreated larvae, while the lowest SA was recorded in larvae treated with Komatch $(46.33 \pm 1.52 \mu \mathrm{g}$ glucose/ $\min /$ g. bwt days ) recorded reduction of $-0.42 \%$ in compared with $(80.0 \pm 4.33 \mu \mathrm{g}$ glucose / $\mathrm{min} / \mathrm{g}$. bwt days) for untreated larvae

In regarding to the effect of $\mathrm{LC}_{25}$ concentration of tested compound on amylase activity in treated and untreated $4^{\text {th }}$ instar larvae tested at 7 days after treatment as SA and RA\% in treated larvae in relation to untreated ones. the highest SA on amylase was recorded in larvae treated with Nomult $(115.3380 .0 \pm 4.333 .72 \mu \mathrm{g}$ glucose / $\mathrm{min} / \mathrm{g}$. bwt days) recorded increase in RA\% by $0.19 \%$ in compared with untreated larvae, while the lowest SA was recorded for larvae treated with Dursban (64.3380.0 $\pm 4.333 .43 \mu \mathrm{g}$ glucose/ $\mathrm{min} / \mathrm{g}$. bwt days) recorded reduction of $-0.34 \%$ in compared with 97.0080.0 $\pm 4.334 .64 \mu \mathrm{g}$ glucose / $\mathrm{min} / \mathrm{g}$. bwt days for untreated larvae .

In case of the results of $\mathrm{LC}_{50}$ treatment after 7 days, the highest SA was recorded in larvae treated with Nomult $(104.67 \pm 3.80 \mu \mathrm{g}$ glucose/ $\mathrm{min} / \mathrm{g}$. bwt days) recorded increase in RA\% $0.08 \%$ in compared with untreated larvae, while the lowest effect was recorded in larvae treated with $\mathrm{Kz}$ oil $(38 \pm 2.52 \mu \mathrm{g}$ glucose/ $\mathrm{min} / \mathrm{g}$. bwt days) recorded reduction of $-0.61 \%$ in compared with $97.00 \pm 4.94 \mu \mathrm{g}$ glucose / $\mathrm{min} / \mathrm{g}$. bwt days) for untreated larvae.

These results found in agreement with those of Wyatt (1957); Wiggles worth (1972); Nathon, et al. (2005) and EL-Sheikh, et al. (2013)stated that, the tested IGRs and $\mathrm{Kz}$ oil effected Amylase activity in $S$. littoralis.

\section{b -Total soluble protein (TSP) assessment:}

Data in Table (5) showed the effect of $\mathrm{LC}_{25}$ concentration of tested compound on TSP levels in treated and untreated $4^{\text {th }}$ instar larvae sampled after 3 days as specific concentration (SC)and relative concentration $(\mathrm{RC} \%)$ in treated larvae in relation to untreated ones. The highest effect on TSP was recorded in larvae treated with Dursban $(38.60 \pm 0.26 \mathrm{mg} / \mathrm{g} . \mathrm{bwt})$ recorded reduction of $-0.18 \%$ in compared with untreated larvae while the lowest effect was recorded in 
larvae treated with Betavant $(21.20 \pm 0.56 \mathrm{mg} / \mathrm{g} . \mathrm{bwt})$ recorded increase of $45.18 \%$ in compared with $38.67 \mathrm{mg} / \mathrm{g} . \mathrm{bwt}$ for untreated larvae.

In thesame trend, the results of sampled larvae treated byLC $\mathrm{C}_{50}$ after 3 days cleared that the highest effect on TSPwas recorded in larvae treated with Dursban $(40.57 \pm 0.59 \mathrm{mg} / \mathrm{g}$. bwt) recorded increase of $5.17 \%$ in compared with untreated larvae while the lowest effect was recorded in larvae treated with Betavant $(17.73 \pm 0.38 \mathrm{mg} / \mathrm{g}$. bwt) recorded increase of $54.15 \%$ in compared with $38.57 \pm 0.26 \mathrm{mg} / \mathrm{g}$.bwt for untreated larvae.

In case of the effect of $\mathrm{LC}_{25}$ concentration of the tested compoundon TSP levels in treated and untreated $4^{\text {th }}$ instar larvae sampled after 7 days as SCand RC\% in treated larvae in relation to untreated ones. The highest effect was recorded in larvae treated withProtecto $(32.63 \pm 0.70 \mathrm{mg} / \mathrm{g}$. bwt) recorded increase of $4.82 \%$ in compared with untreated larvae, while the lowest effect was recorded in larvae treated with $\mathrm{Kz}$ oil $(23.87 \pm 0.65 \mathrm{mg} / \mathrm{g} . \mathrm{bwt})$ recorded increase of $23.32 \%$ in compared with $31.13 \mathrm{mg} / \mathrm{g} . \mathrm{bwt}$ ) for untreated larvae.In the same trend the results of the effect on larvae treated with $\mathrm{LC}_{50}$ treatment after 7 days cleared that,the highesteffect on TSP was recorded in larvae treated with Protecto $(33.37 \pm 0.54 \mathrm{mg} / \mathrm{g} . \mathrm{bwt})$ recorded increase of $7.20 \%$ in compared with untreated larvae while the lowest effect was recorded in larvae treated with Nomult $(18.90 \pm 0.38 \mathrm{mg} / \mathrm{g} . \mathrm{bwt})$ recorded increase of $39.29 \%$ in compared with31.13 $\pm 1.56 \mathrm{mg} / \mathrm{g}$.bwt for untreated larvae that after 7 days of treatment with $\mathrm{LC}_{50}$ concentration. These results found agree those of ELKordyet al.(1995); Zidanet al.(1996);Desuky, et al.(2005);Gamilet al.(2011) andBasiouny, et al.(2016)thattested compounds effected TSP in $S$. littoralisand other insects.

Table (5): Changes of total soluble protein levels in $\mathrm{S}$. littoralis treated with multiple compounds and chemical pesticide

\begin{tabular}{|c|c|c|c|c|c|c|c|c|c|c|c|c|c|c|c|}
\hline \multirow[b]{2}{*}{ Treatments } & \multirow{2}{*}{ 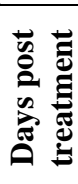 } & \multirow{2}{*}{ 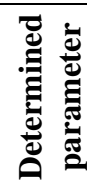 } & \multicolumn{2}{|c|}{ Komatch } & \multicolumn{2}{|c|}{ Nomolt } & \multicolumn{2}{|c|}{ Betavant } & \multicolumn{2}{|c|}{ Kzoil } & \multicolumn{2}{|c|}{ Protecto } & \multicolumn{2}{|c|}{ Dursban } & \multirow[b]{2}{*}{ control } \\
\hline & & & 25 & 50 & 25 & 50 & 25 & 50 & 25 & 50 & 25 & 50 & 25 & 50 & \\
\hline \multirow{6}{*}{ 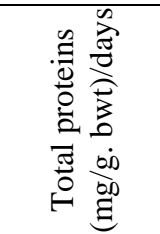 } & & & 31.53 & 23.03 & 34.17 & 31.20 & 21.20 & 17.73 & 35.90 & 36.30 & 2577 & 25.57 & 38.60 & 40.57 & \multirow{3}{*}{$\begin{array}{l}38.67 \\
\pm 0.85\end{array}$} \\
\hline & $\begin{array}{c}3 \\
\text { davs }\end{array}$ & & \pm 0.59 & \pm 0.58 & \pm 0.38 & \pm 0.39 & \pm 0.56 & \pm 0.38 & \pm 0.80 & \pm 0.74 & \pm 0.55 & \pm 0.24 & \pm 0.26 & \pm 0.59 & \\
\hline & days & $\mathrm{RC} \%$ & -18.46 & -30.10 & -11.64 & -19.32 & -45.18 & -54.15 & -7.16 & -6.13 & -33.36 & -33.88 & -0.18 & 5.17 & \\
\hline & & & 24.10 & 24.70 & 25.83 & 18.90 & 26.07 & 20.57 & 23.87 & 20.77 & 32.63 & 33.37 & 30.33 & 20.13 & \\
\hline & 7 & $\mathrm{SC}$ & \pm 0.20 & \pm 0.61 & \pm 0.38 & \pm 0.55 & \pm 0.87 & \pm 0.65 & \pm 0.65 & \pm 0.65 & \pm 0.70 & \pm 0.54 & \pm 0.38 & \pm 1.21 & +1 \\
\hline & days & $\mathrm{RC} \%$ & -22.58 & -20.66 & -17.03 & -39.29 & -16.26 & -33.92 & -23.32 & -33.33 & 4.82 & 7.20 & 3.13 & -35.34 & (. \\
\hline
\end{tabular}

$\overline{\mathrm{SC}}=$ Specific concentration

RC\% = Relative concentration

Treatment - control

RC $\%=\times-\frac{\text { Control }}{\text { Con }} 100$

\section{c- Transaminase activities:}

Data in table (5) showed the changes in GOT, GPT activities as the concentration of the formed pyruvate and the relative activity as a percentage of formed pyruvate for treated larvae in comparable with untreated ones. The obtained results cleared that the all tested compoundaffected the transaminase activities positively or negatively as follows:

- The effect on Aspartate amino transferase (GOT):

Data in table (6) showed the effect of $\mathrm{LC}_{25}$ concentration of tested compound onGOT activity in treated and untreated $4^{\text {th }}$ instar larvae sampled after 3 days of treatment as specific activity (SA) and relative activities (RA\%) in treated larvae in relation to untreated ones. The highest effect was recorded in larvae treated with $\mathrm{Kz}$ oil $\left(2574.33 \pm 30.41 \mathrm{u}^{*} 10^{3} \mathrm{~g}\right.$.bwt $)$ recorded increase of $0.33 \%$ in compared with untreated larvae while the lowest effect was recorded in larvae treated with Betavant $\left(1441.67 \pm 24.56 \mathrm{u}^{*} 10^{3} / \mathrm{g} . \mathrm{bwt}\right)$ recorded reduction of $(-26.36 \%)$ in compared with $\left(1957.67 \pm 29.19 u^{*} 10^{3}\right.$ g.bwt) for untreated larvae.

In the same trend the results of the affected treated larvae withLC $\mathrm{C}_{50}$ treatment after 3 days cleared that, the highest effect was inspected in larvae treated with $\mathrm{Kz}$ oil $\left(2305 \pm 7.88 \mathrm{u}^{*} 10^{3} \mathrm{~g}\right.$.bwt) recorded increase of $31.50 \%$ in compared with untreated larvae, while the lowest effect was recorded in larvae treated with
Betavant $\quad\left(1266.67 \pm 4.25 \quad \mathrm{u}^{*} 10^{3} \quad\right.$ g.bwt $)$ recorded reduction of $-35.30 \%$ in compared with $(1957.67 \pm 29.19$ $\mathrm{u} * 10^{3} \mathrm{~g}$.bwt) for untreated.

In regarding to the effect of $\mathrm{LC}_{25}$ concentration of the tested compound on GOT activities in treated and untreated $4^{\text {th }}$ instar larvae sampled at 7 days after treatment as SA and RA\% intreated larvae in relation to untreated ones. The highest SA was recorded in larvae treated with Komatch $\left(1615 \pm 9.88 \mathrm{u} * 10^{3} \mathrm{~g}\right.$. bwt $)$ recorded increase in RA\% by $9.86 \%$ in compared with untreated larvae, while the lowest effect was recorded in larvae treated with Dursban $\left(832.57 \pm 19.40 \mathrm{u} * 10^{3} \mathrm{~g}\right.$. bwt) recorded reduction of $-43.36 \%$ compared with $1470 \pm 65.65 \mathrm{u}^{*} 10^{3} \mathrm{~g}$.bwt) for untreated larvae.

In the same trend the results of $\mathrm{LC}_{50}$ treatment after 7 days cleared that, the highest SA was recorded in larvae treated with Komatch $\left(1509 \pm 5.14 \mathrm{u} * 10^{3}\right.$ g.bwt) recorded increase in RA\% by $2.65 \%$ in compared with untreated larvae, while the lowest effect was recorded in larvae treated with Dursban $\left(601.00 \pm 9.55 \mathrm{u}^{*} 10^{3} \mathrm{~g}\right.$.bwt) recorded reduction of $-59.12 \%$ in compared with $\left(1470 \pm 65.65 \mathrm{u}^{*} 10^{3} \mathrm{~g}\right.$.bwt) for untreated larvae.

The obtained results found in agreement with those of Ahmed,et al. (1990); EL-Kordy, et al. (1995);Zidan,et al. (1995);Kandil (2005) and Omar,et al. (2005)that the mineral oil affected GOT activities in S. Littoralis 
Table (6):Changes of total soluble protein levels, GOT and GPT activities inS. littoralis treated with multiple compounds and chemical pesticide.

\begin{tabular}{|c|c|c|c|c|c|c|}
\hline \multirow{2}{*}{ Treatments } & \multirow{2}{*}{\multicolumn{2}{|c|}{ Con. ppm }} & \multicolumn{2}{|c|}{ GOT (Ux $10^{3}$ g. bwt) } & \multicolumn{2}{|c|}{ GPT (Ux 10 ${ }^{3}$ g. bwt) } \\
\hline & & & 3 days & 7 days & 3 days & 7 days \\
\hline \multirow{4}{*}{ Komatch } & \multirow{2}{*}{25} & SA & $1951.00 \pm 11.73$ & $1615.00 \pm 9.88$ & $711.33 \pm 5.20$ & $502.33 \pm 7.23$ \\
\hline & & $\mathrm{RA} \%$ & -0.34 & 9.86 & 16.42 & 9.84 \\
\hline & \multirow{2}{*}{50} & SA & $2044.67 \pm 22.65$ & $1509.00 \pm 5.14$ & $667.33 \pm 12.79$ & $454.67 \pm 7.37$ \\
\hline & & RA \% & 0.05 & 2.65 & 9.22 & -0.58 \\
\hline \multirow{4}{*}{ Nomolt } & \multirow{2}{*}{25} & $\mathrm{SA}$ & $1937.00 \pm 27.04$ & $1511.67 \pm 22.45$ & $587.33 \pm 33.15$ & $404.67 \pm 5.18$ \\
\hline & & $\mathrm{RA} \%$ & -1.06 & 2.84 & -3.87 & -11.52 \\
\hline & \multirow{2}{*}{50} & SA & $1900.67 \pm 20.90$ & $1482.00 \pm 10.52$ & $637.33 \pm 14.63$ & $322.67 \pm 4.66$ \\
\hline & & $\mathrm{RA} \%$ & -2.91 & 0.82 & 4.31 & -29.45 \\
\hline \multirow{4}{*}{ Betavant } & \multirow{2}{*}{25} & SA & $1441.67 \pm 24.56$ & $980.00 \pm 30.59$ & $397.67 \pm 2.77$ & $395.00 \pm 7.27$ \\
\hline & & $\mathrm{RA} \%$ & -26.36 & -33.33 & -34.92 & -13.63 \\
\hline & \multirow{2}{*}{50} & $\mathrm{SA}$ & $1266.67 \pm 4.25$ & $1046.33 \pm 27.54$ & $219.67 \pm 7.85$ & $305.67 \pm 5.18$ \\
\hline & & RA \% & -35.30 & -28.82 & -64.05 & -33.16 \\
\hline \multirow{4}{*}{ KZoil } & \multirow{2}{*}{25} & SA & $2574.33 \pm 30.41$ & $1553.33 \pm 19.19$ & $384.00 \pm 13.91$ & $256.67 \pm 12.19$ \\
\hline & & $\mathrm{RA} \%$ & 0.32 & 5.67 & -36.66 & -43.88 \\
\hline & \multirow{2}{*}{50} & SA & $2305.00 \pm 7.88$ & $1489.67 \pm 9.18$ & $241.00 \pm 12.11$ & $221.67 \pm 11.48$ \\
\hline & & RA $\%$ & 31.50 & 1.16 & -60.06 & -51.53 \\
\hline \multirow{4}{*}{ Protecto } & \multirow{2}{*}{25} & SA & $2002.67 \pm 11.07$ & $1526.67 \pm 16.73$ & $636.33 \pm 7.01$ & $457.67 \pm 8.46$ \\
\hline & & RA $\%$ & 0.18 & 3.39 & 4.15 & 0.08 \\
\hline & & SA & $1863.33 \pm 56.90$ & $1461.67 \pm 17.07$ & $699.33 \pm 4.26$ & $537 \pm 18.79$ \\
\hline & 50 & RA \% & -4.82 & -0.06 & 14.46 & 17.42 \\
\hline \multirow{5}{*}{ Dursban } & \multirow{2}{*}{25} & SA & $1821.00 \pm 10.16$ & $832.67 \pm 19.40$ & $323.67 \pm 5.59$ & $238.67 \pm 8.18$ \\
\hline & & $\mathrm{RA} \%$ & -6.98 & -43.36 & -61.92 & -47.81 \\
\hline & \multirow{2}{*}{50} & $\mathrm{SA}$ & $1917.67 \pm 23.38$ & $601.00 \pm 9.55$ & $303.67 \pm 7.01$ & $259.33 \pm 10.99$ \\
\hline & & RA $\%$ & -7.15 & -59.12 & -50.30 & -43.30 \\
\hline & & & $1957.67 \pm 29.19$ & $1470.00 \pm 65.65$ & $611.00 \pm 13.29$ & $457.33 \pm 23.98$ \\
\hline
\end{tabular}

SA= Specific activity

RA \% = Relative concentration

Treatment - control

RA \% $=\times-\frac{}{\text { Control }} 100$

\section{- Alanine amino transferase (GPT)}

Data in table (6) showed the effect of $\mathrm{LC}_{25}$ concentration of tested compound on GPT activity in treated and untreated $4^{\text {th }}$ instar larvae sampled after 3 days of treatment as specific activity (SA) and relative activity (RA\%) in relation to untreated ones .The highest effect on GPT was recorded in larvae treated with Komatch $\left(711.33 \pm 5.20 \mathrm{u} * 10^{3}\right.$ g.bwt $)$ recorded increase of $16.42 \%$ incompared with untreated larvae, while the lowest SA was recorded in larvae treated with Dursban $\left(323.60 \pm 5.39 \mathrm{u} * 10^{3} \mathrm{~g}\right.$.bwt) recorded reduction of $-61.92 \%$ in compared with $611.00 \pm 13.29$ $\mathrm{u}^{*} 10^{3} \mathrm{~g}$. bwt) for untreated larvae.

In the same trend, the results of $\mathrm{LC}_{50}$ treatment after 3 days cleared that,the highest SA was recorded in larvae treated with Protecto $\left(699.33 \pm 4.25 \mathrm{u} * 10^{3} \mathrm{~g} . \mathrm{bwt}\right)$ recorded increase of $14.46 \%$ in compared with untreated larvae, while the lowest AS was recorded for Betavant $\left(219.67 \pm 7.83 \mathrm{u} * 10^{3} \mathrm{~g}\right.$.bwt) recorded reduction of $64.05 \%$ in compared with $\left(611 \pm 13.29 \mathrm{u}^{*} 10^{3} \mathrm{~g} . \mathrm{bwt}\right) \mathrm{SA}$ for untreated larvae.

In regarding to the effect of $\mathrm{LC}_{25}$ concentration of tested compound on GPT activity in treated and untreated $4^{\text {th }}$ instar larvae sampled after 7 days as SA andRA\% in treated larvae in relation to untreated ones. The highest AS was recorded in larvae treated with Komatch $\left(502.33 \pm 7.23\right.$ u $* 10^{3}$ g.bwt $)$ recorded increasein RA\% by $9.84 \%$ in compared with untreated larvae, while the lowest effect was recorded for larvae treated with Dursban $\left(238.67 \pm 8.18 \mathrm{u} * 10^{3}\right.$ g.bwt) recorded reduction of $-47.81 \%$ in compared with $\left(457.23 \pm 23.98 \mathrm{u} * 10^{3} \mathrm{~g}\right.$.bwt) for untreated larvae.

In the same trend the results of $\mathrm{LC}_{50}$ concentration after 7 days cleared that, the highest SA recorded in larvae treated with Protecto $(537 \pm 18.79 \mathrm{u}$ $* 10^{3}$ g.bwt) recorded increase of $17.42 \%$ in compared with untreated larvae, while the lowest effect was recorded in larvae treated with $\mathrm{Kz}$ oil $(221.67 \pm 11.48 \mathrm{u}$ $* 10^{3}$ g.bwt) recorded reduction of $-51.53 \%$ in compared with $\left(457.33 \pm 23.98 \mathrm{u} * 10^{3}\right.$ g.bwt $)$ for untreated larvae.These results relatively in affinity with those of EL-Kordy, et al. (1995);Kandil (2005);Abou-Taleb,et al.(2015); and Hamadah, et al.(2016).The mineral oil effected GPT activity in $S$. littoralis.

\section{REFERENCES}

Abou-Taleb H.K., Zahran H. E. M. and Abir - Gad, A. (2015):Biochemical and physiological effects of Lufenuron Chlorfluazuron on Spodoptera littoralis (Boisd.)(Lepidoptera:Noctuidae). J.of Entomol.,12(2):77-86. 
Ahmed, Y.M.; A.M.A. Mostafa and A. Shoukry(1990).Effect of chlorfluazuron on transaminase activity in larvae and pupae of $S$. littoralis (Boisd.).Med. Fac. Landbouww .Rijksaniv. Gent.,55(2b):621-627.

AL-Shannaf, H. M. H. and Ammar, A. E. (2011): Several tools used to control cotton leafworm spodoptera littoralis (Boisd) and American Bollworm Helicoverpaarmigera (HUB) in peanut fields. Bull.Fac.Agic. Cairo Univ.,62: 503-510.

AL-Shnnaf, H. M. H. ; Hala, M. M. andKasafy, H.S. (2012): toxic and biochemical effects of same bioinsecticides and IGRs on American Bollworm Helicoverpaarmigera (HUB) (Lepidoptera: Noctuidae) in cotton Field. J. Biofertil. Biopestici.,3 (2): 1-6.

Ayyangar, G. S. G. and Rao, P. J. (1990). Changes in heamolymph constituents of Spodopteralitura (Fabr.) under the influence of azadirachtin .Indian. J. Entomol.,52 (1): 69 - 83.

Barrania (2013):Antifeedant,GrowthInhibtory and Toxicity effects of Chlorantraniliprole, Thiamethoxam and Novaluron the cotton leafworm, Spodoptera littoralis (Boisd.) (Lepidoptera : Noctuidae) In cotton fields. Egypt.J.Agric.Rec., 91(3):903-911.

Basiouny, K. Ghoneim ,M. Tanani ,Kh. Hamadah, and H.Waheeb (2016). Disturbed protein content in Egyptian cotton leafworm Spodoptera littoralis (Boisd.)(Lepidoptera:Noctuidae) by some novel chitin synthesis inhibitors.Int. J. Adv. Res. Biol. Sci., 3(3):1-12.

Bradford, M.M. (1976): A rapid and sensitive method for the quantitation of microgram quantities of protein utilizing the principle of protein- dye binding. Anal.Biochem.,72:248-254.

Desuky, W. M. H.; Kheder, M. M. A. ; Youssif, K. S. I.and EL-Shakaa, S. M. A. (2005): Field and biochemicalstudies on some compound against cotton leafworm Spodopteralittoralis (Boisd).Egypt J.Agric. Res.,83 (3): 1087-1106.

El-Kordy, M.W.; A.I. Gadallah, M.G.; Abbas and S. A. Mostafa.(1995).Effect of pyriproxyfen, flufenoxuron and teflubenzuron on some biochemical aspects of Spodopteralittoralis. AlAzharJ. Agric.Res., 21:223-238. EL-Sheikh, T.A.A.,HebaS.Rafea,A.M.EL-AasarandS. Ali (2013) : Biological an Biochemical effects of Bacillus thuringiensis, Serratiamarcescens and teflubenzuron on cotton leafworm. Egypt. Agric. Res., 911(4): 1327-1345.

Gamil, W. E.; Mariy, F. M.; Youssef, L. A. and Halim, S. M. A. (2011): Effect of indoxacarb on some biological and Biochemical aspects of Spodoptera littoralis (Boisd) larvae.Ann. Agric. Sci.,56 (2): 137-142.

Hamadah, Kh.;GhoneimK.; Anani M.; Basiouny A. and Waheeb H. (2016): Deteriorated acid and alkaline phosphatase activities in certain tissues of Spodoptera littoralis(Lepidoptera:Noctuidae) by some novel chitin synthesis Inhibitors.Int. J. Adv. Res. Biol. Sci.,4(2):611-624.
Henderson, C. F. and Tilton,E. W. (1955): tests with acaricides against the brown wheat mite. J. Econ.Entomol.,48:157-161.

Ishaaya, I.andSwiriski,E. (1976) : Trehalase,invertase andamylase activities in the black scale insect,Sissetiaoleae and their relation to host adaptability. J. Insc. Physiol., (16):1025-1029.

Kandil, M.A.; T.R.A. El-Zaher.; and A. M. Rashad (2005):Some biological and biochemical effects of chitin synthesis inhibitors on pink bollworm Pectinophoragossypiella (Saunders) .Ann .Agric. Sci. Moshtohor. 43(4): 1991-2002.

Khatter, N. A. and Abuldahb, F. F. (2010):Effect ofRicinuscomnus,Brassica nigra and mineral oil kemesol on some biochemical aspects of larvae stage of Sodoptera littoralis (Boisd.) (Lepidoptera: Noctuidae).EgyptSoci. ofparasitol.,40 (1): 151-158.

Mohamed, S. A.; Mousa, G. M. and EL-Sisi, A. G. (2006):Pesticidal efficiency of the mineral oil, CAPL-2 alone or mixed with actellic against cabbage aphid Brevicorynebressicae L and cotton leafworm Spodoptera littoralis (Boisd.) attacking cabbage plants. J. Agric. Res.,84 (1): 75-81.

Nathan, S. S.; P.G. Chung and M. Kadarkarai (2005):Combined effect of biopesticides on the digestive enzymatic profiles of Cnaphalocrocismedinalis (Guenee) (the rice leaffolder) (Insecta : Lepidoptera: Pyralidae). Ecotoxicology and Environmental Safety, 64(3): 382-389.

Omar,R.E.M.;Desuky,W.M.H.;Darwish,A.A.A.andAme r,A.E.A.(2005):Biochemical and histological effects of chinmixspintor and Biorepelcompounds on larvae of pink and spiny Bollworms. Ann. Agric. Sci., Moshtohor, 44 (1): 279-289.

Pluschkell, U. A. R.; Weintraub, H.P. G., andIshaaya,W. (1998): DPX-MPO62- a potent compound for controlling the Egyption cotton leafworm Spodoptera littoralis (Boisd.).Pestic. Sci.,54: 85-90.

Reitman, S. M. andFrankel, S. (1957): A colorimetric method for determination of serum glutamic pyruvic transaminase. J. Clin. Path., (28): 56-63.

Sabry,H.M.andKhedr,M.A.(2014):Biochemical and Histological variation induced by IGRs inSpodoptera littoralis (Boisd.) Glob.J.Environ.Sci.Toxicol.,1(2):163-178.

Wyatt, G. R. (1967):The biochemistry of sugars and polysaccharides in insects. Adv. Insect Physiol., 4: 287-360.

Zidan, Z. H.; Moawad, G. M.; Gadallah,A. I. and ELSwerki, F. E. (1996): Biochemical aspects of the cotton leafworm larvae Spodoptera littoralis (Boisd.) as affected by safenontoxic insecticides. Proc. $6^{\text {th }}$ Conf. of Agric.Devel. Res. 17-19 Dec. Cairo, Ann. of Agric. Sci., 233-244. 


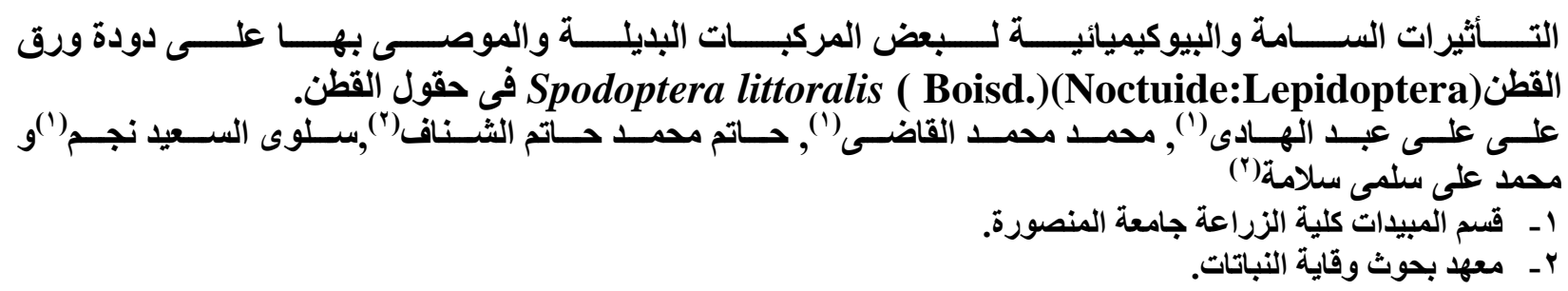

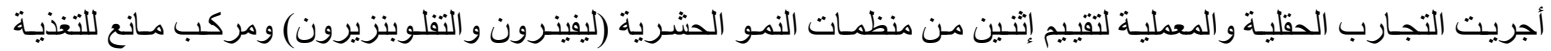

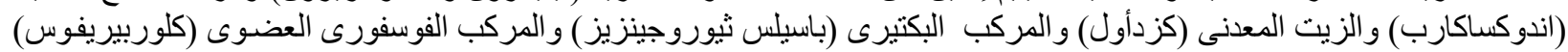
وذللك ضد يرقات دودة ورق الزبت القطنى .

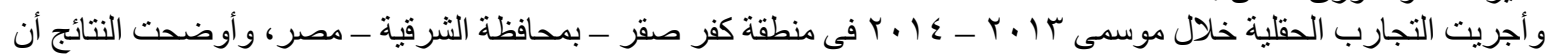

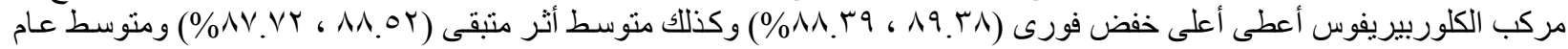

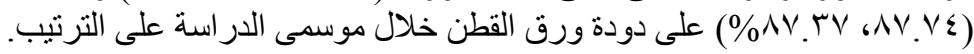

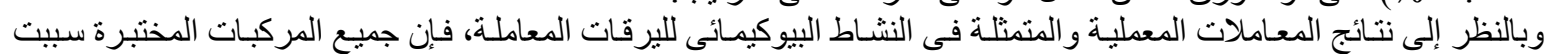

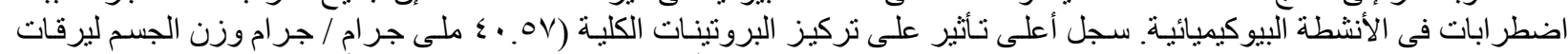

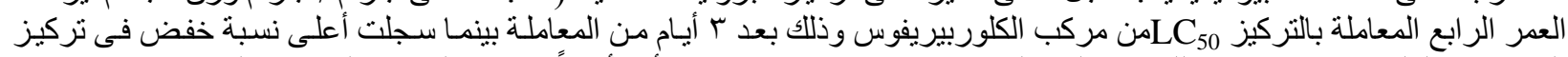

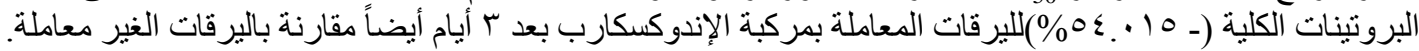

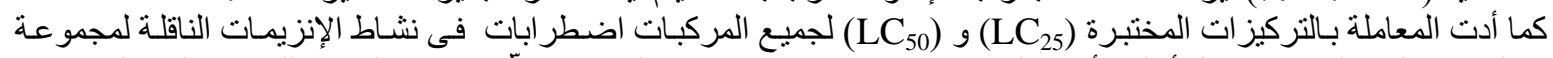

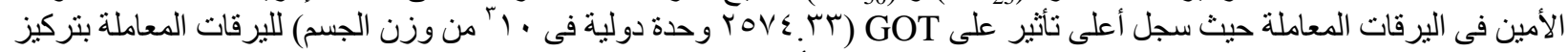

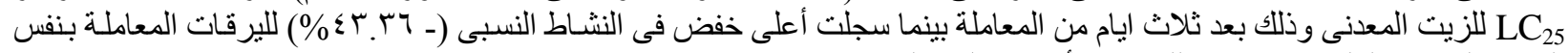

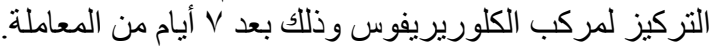

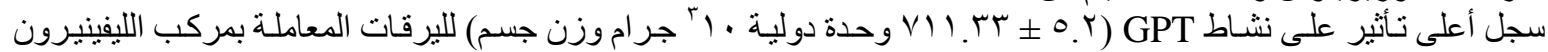

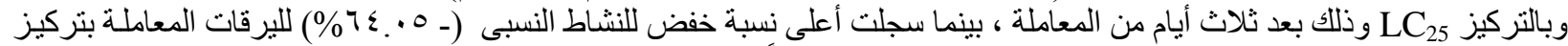

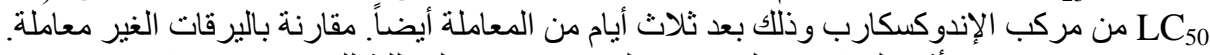

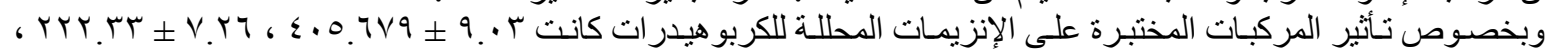

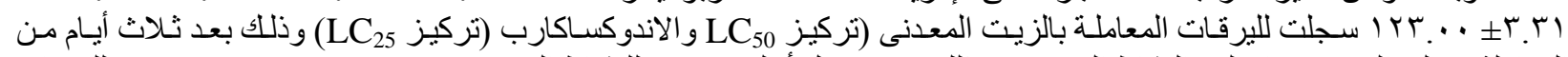

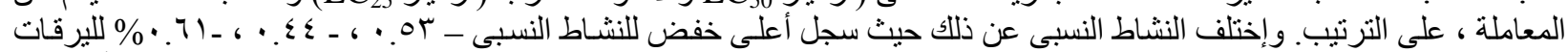
المعاملة بتركيز LC

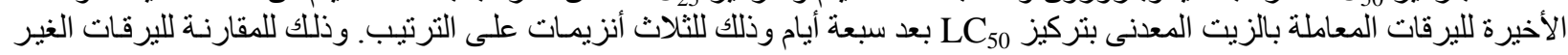

